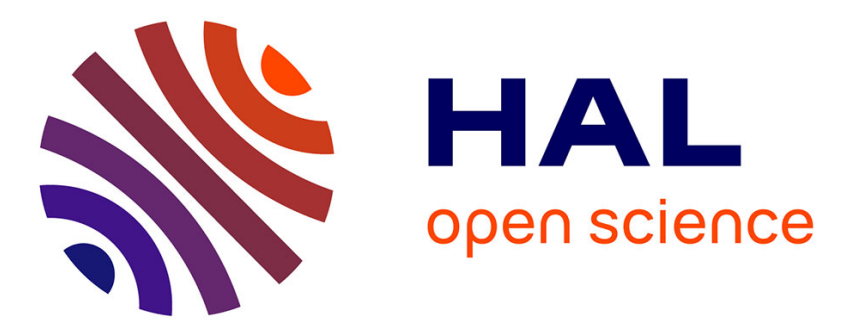

\title{
Gas chromatography-mass spectrometry study of polycyclic aromatic hydrocarbons in grass and milk from urban and rural farms
}

Nathalie Grova, Claire Laurent, Cyril Feidt, Guido Rychen, François Laurent, Eric Lichtfouse

\section{- To cite this version:}

Nathalie Grova, Claire Laurent, Cyril Feidt, Guido Rychen, François Laurent, et al.. Gas chromatography-mass spectrometry study of polycyclic aromatic hydrocarbons in grass and milk from urban and rural farms. European Journal of Mass Spectrometry, 2000, 6 (5), pp.457-460. 10.1255/ejms.371 . hal-00263404

\section{HAL Id: hal-00263404 \\ https://hal.science/hal-00263404}

Submitted on 12 Mar 2008

HAL is a multi-disciplinary open access archive for the deposit and dissemination of scientific research documents, whether they are published or not. The documents may come from teaching and research institutions in France or abroad, or from public or private research centers.
L'archive ouverte pluridisciplinaire HAL, est destinée au dépôt et à la diffusion de documents scientifiques de niveau recherche, publiés ou non, émanant des établissements d'enseignement et de recherche français ou étrangers, des laboratoires publics ou privés. 
Revised version

European Journal of Mass Spectrometry 6, 457-460, 2000. doi: 10.1255/ejms.371

Correspondence: Dr. Eric Lichtfouse, INRA-CMSE-PME, 17, rue Sully, 21000 Dijon, France

Eric.Lichtfouse@dijon.inra.fr

\title{
Gas chromatography-mass spectrometry study of polycyclic aromatic hydrocarbons in grass and milk from urban and rural farms
}

\author{
Nathalie GROVA ${ }^{1}$, Claire LAURENT ${ }^{1}$, Cyril FEIDT $^{1}$, \\ Guido RYCHEN ${ }^{1}$, François LAURENT ${ }^{1}$, Eric LICHTFOUSE ${ }^{2}$ \\ ${ }^{1}$ Laboratoire de Sciences Animales, ${ }^{2}$ Laboratoire Sols et Environnement, \\ ENSAIA-INPL-INRA, BP 172, 54505 Vandoeuvre-lès-Nancy, France.
}

\begin{abstract}
PAH levels were studied in grass and milk sampled at two farms, one located in a noncontaminated, rural area, and another located in a urban area close to PAH sources such as highways, high-traffic roads, fuel-powered trains and a steel plant. PAH concentration were measured by gas chromatography coupled to mass spectrometry (GC-MS) using internal deuteriated standards. In grasses, unexpectedly, although the sum of PAH concentrations was only slightly higher at the urban farm $(83.1 \pm 16.1 \mathrm{ng} / \mathrm{g})$ versus rural farm $(51.8 \pm 10.6 \mathrm{ng} / \mathrm{g})$, this difference was not observed for all PAH members. This absence of striking difference of PAH levels between urban and rural grasses suggests that atmospheric PAH sources, e.g. vehicle exhausts and chimney fumes, could be rapidly diluted by winds. In milk, PAH concentrations were not significantly different at urban and rural farms.
\end{abstract}

\section{Introduction}

Polycyclic aromatic hydrocarbons are potentially mutagenic compounds widely occurring in natural media such as soils, atmosphere, sediments and plants (Edwards, 1983, Sims and Overcash, 1983, Baek et al., 1991, Wilson and Jones, 1993, Richnow et al., 1995, Wild and Jones, 1995, Henner et al., 1997, McRae et al., 1999, Lichtfouse et al. 1999, Wilcke, 2000, Bryselbout et al., 2000). There are natural as well as anthropogenic sources of PAHs such as vegetation fires, petroleum seepage and vehicle exhausts. The main known processes of PAH formation are 1) incomplete combustion of organic matter, e.g. fuel and wood burning (Freeman and Cattell, 1990) 2) the slow maturation of sedimentary organic matter to yield fossil fuels, e.g. coal and petroleum (Tissot et al., 1971), and 3) the rapid aromatisation of organic substances in modern sediments (Trendel et al., 1989). Noteworthy, a recent study of termite nests and wood points to a possible - modern - biological origin of PAHs (Wilcke et al., 2000).

While the sources of PAHs in heavily-contaminated environmental samples, e.g. coke-plant soils or highway plants, are rather easy to pinpoint, the precise origin of PAH occurring at trace levels is poorly known due to our lack of knowledge of transfer pathways (Simonich and Hites, 1994, Lichtfouse et al., 1997). More specifically, there is a strong need to study the relationships between plant contamination and food contamination (Eisele, 1985, Travis and Arms, 1988). Here we wish to report a comparison of PAH levels in grasses and milk from rural and urban farms. 


\section{Experimental}

\subsection{Grass and milk samples}

Milk and grass samples were collected in July 2000 at two farms in Lorraine, France. One farm is located in a very remote, rural area, far away from major sources of PAHs such as highways and industrial activities. The other farm is located in a high-traffic zone of the suburbs of a major town in Lorraine, at $700 \mathrm{~m}$ from a steel factory, $500 \mathrm{~m}$ from fuel-powered railway trains, and $4 \mathrm{kms}$ from two major highways. All sampling ware was pre-washed successively with distilled water, acetone, and then hexane. At each farm, five grass samples were collected in dairy cattle-meadows. This grass was the sole food source of the cows (in summer). Each grass sample of about $1 \mathrm{~kg}$ is the sum of 8 sub-samples collected on a circle of $10-\mathrm{m}$ radius. The five grass samples were dried at room temperature, finely ground then mixed together. Five $10 \mathrm{~g}$ sub-samples were analysed. Five milk samples of $500 \mathrm{ml}$ were collected at the cooled tank $\left(4^{\circ} \mathrm{C}\right)$ of the farm, then stored at $-20^{\circ} \mathrm{C}$.

\subsection{PAH analysis}

Detailed extraction procedures are described in the NF ISO 15302 method, and were conducted by Micropolluant Technologie Ltd. PAH were quantified by gas chromatography coupled to mass spectrometry (HP) in the single ion monitoring mode, using internal deuterated standards : naphthalene- $d_{8}(\mathrm{~m} / \mathrm{z} 136)$ for naphthalene; acenaphthene- $d_{10}(\mathrm{~m} / \mathrm{z} 164)$ for acenaphthene, acenaphtylene, and fluorene; phenanthrene- $d_{10}(\mathrm{~m} / \mathrm{z} 188)$ for phenanthrene, anthracene, fluoranthene and pyrene; chrysene- $d_{12}(\mathrm{~m} / \mathrm{z} 240)$ for chrysene and benzo[a]anthracene, and perylene- $d_{12}(\mathrm{~m} / \mathrm{z}$ 264) for perylene, benzo[b]fluoranthene, benzo[k]fluoranthene, and benzo[a]pyrene. Analytical detection levels : $0.50 \mathrm{ng} \mathrm{PAH} / \mathrm{g}$ grass, $0.25 \mathrm{ng} \mathrm{PAH} / \mathrm{g}$ milk fat. Results were statistically analysed with the SAS system software using the GLM procedure (SAS, 1996).

\section{Results and discussion}

\subsection{PAHs in grasses}

The concentration of PAHs in grasses from rural and urban farms is reported on Table 1 and Figure 1. PAH concentrations were measured by GC-MS in the single ion monitoring mode using internal deuteriated standards : naphthalene- $d_{8}(\mathrm{~m} / \mathrm{z} 136)$, phenanthrene- $d_{10}(\mathrm{~m} / \mathrm{z} 188)$, chrysene- $d_{12}(\mathrm{~m} / \mathrm{z} 240)$, perylene- $d_{12}(\mathrm{~m} / \mathrm{z} 264)$. A such procedure allows to quantify trace levels of PAHs in biological samples (Baumard et al., 1997). The sum of PAH concentrations is slightly higher in urban meadow grass $(83.1 \pm 16.1 \mathrm{ng} / \mathrm{g})$ versus rural grass $(51.8 \pm 10.6$ $\mathrm{ng} / \mathrm{g})$. Nonetheless, PAH concentrations are statistically different only for three members: phenanthrene $(P<0.01)$, anthracene $(P<0.001)$, and fluoranthene $(P<0.001)$. These results are rather unexpected because the urban farm is located in a high-traffic area, near a steel plant, two major highways, and a fuel-powered train. Indeed, phenanthrene levels $(31.1 \mathrm{ng} / \mathrm{g})$ in the urban farm are about 100 times lower than those found in grasses located at $4 \mathrm{~m}$ of a Lorraine highway (Bryselbout et al., 2000). It is therefore suggested that PAHs from point sources, e.g. vehicle exhausts, could be rapidly diluted by winds in the vicinity of the point source, then reach the average background level of the atmosphere. Further, in grasses, the predominance of low molecular-weight PAHs and the absence of high molecular-weight PAHs, e.g. perylene, benzo[b]fluoranthene, and benzo[a]pyrene (Figure 1) are in agreement with the distillation effect proposed by Bryselbout et al. (2000) to explain the behaviour of PAH concentrations near highways. 
Table 1. Concentrations of polycyclic aromatic hydrocarbons in grass and milk from urban and rural areas, expressed in $\mathrm{ng} / \mathrm{g}$ grass dry weight, $\mathrm{ng} / \mathrm{g}$ milk fat.

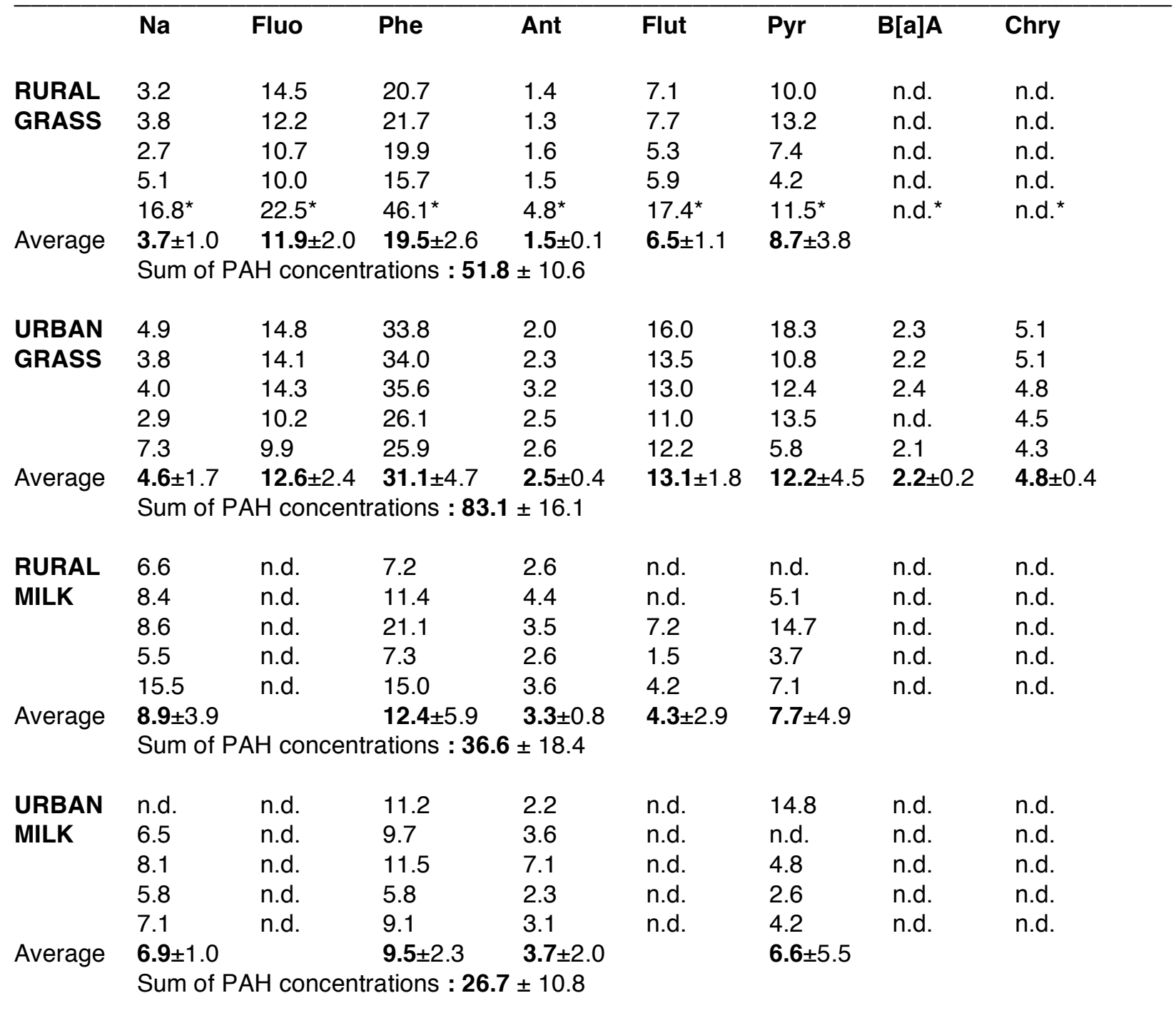

$\mathrm{Na}$ : naphthalene, Fluo : fluorene, Phe : phenanthrene, Ant : anthracene, Flut : fluoranthene, Pyr : pyrene, B[a]A : benz[a]anthracene, Chry : chrysene. n.d. : not detected. *statistically anomalous values not taken into account for averaging.

\subsection{PAH in milk and grasses}

PAH concentrations in urban and rural milk are not statistically different, suggesting a similar source (Table 1, Figure 1). On the contrary, comparison of PAH distributions in grasses and milk show notable differences. Indeed PAH distributions in milk show higher relative concentrations of naphthalene, and the absence of high molecular weight PAHs. This result could be partly explained by the higher water-solubility of naphthalene favouring its selective concentration during digestion. This hypothesis is supported by food chain studies showing that the absorption of polychlorinated dibenzo- $p$-dioxins (PCDDs) and dibenzofurans (PCDF), compounds of close chemical properties as PAHs, decreases with molecular weight (McLachlan, 1995). Nonetheless, several yet unknown processes may account for the PAH distribution in milk. Moreover, there are alternative, presumable sources of milk PAHs such as field drinking water (about 40 l/day), breathing air, and soil (about $600 \mathrm{~g} /$ day) ingested with grass. 


\section{PAHs IN GRASS AND MILK}

Figure 1
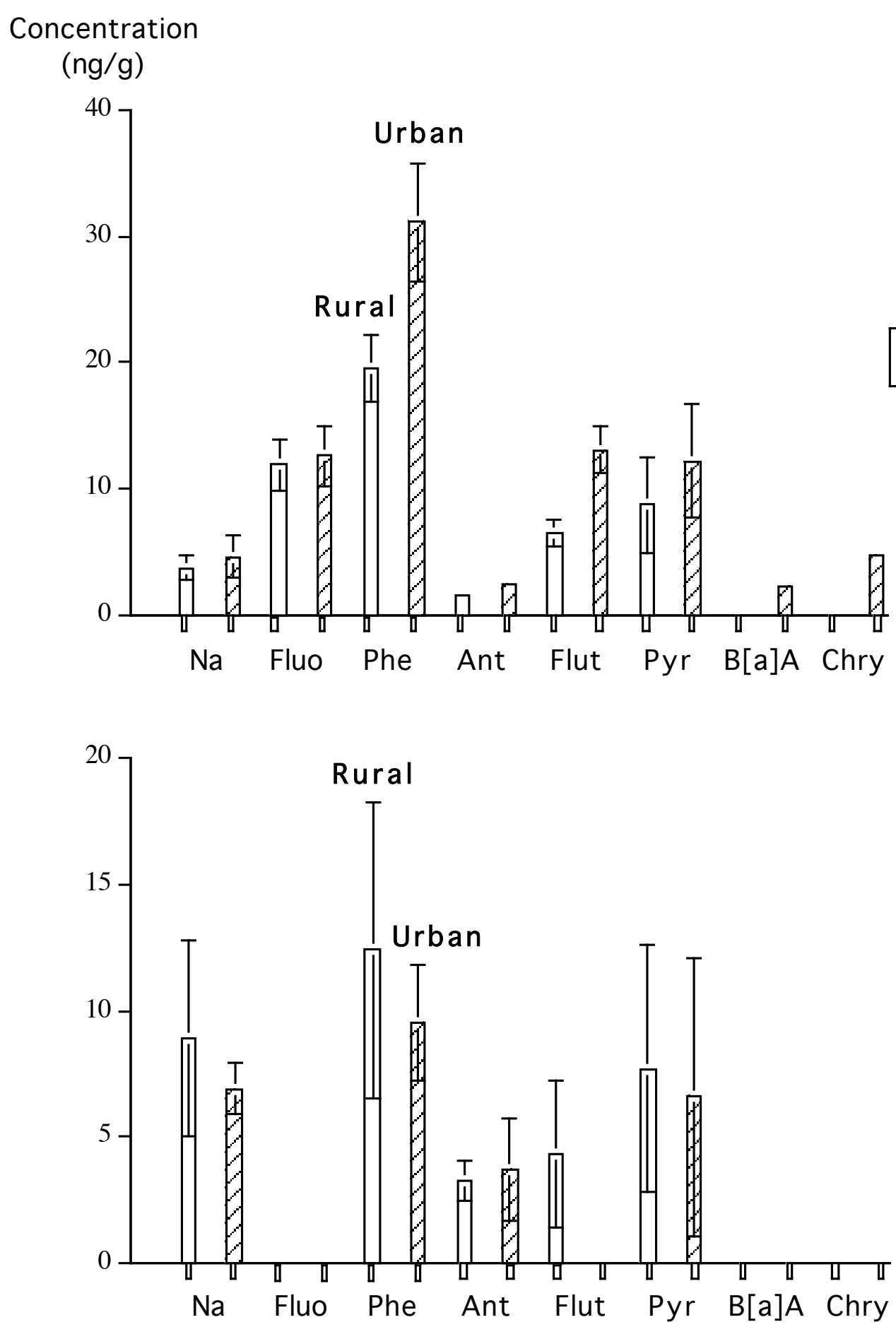

GRASS

MILK

Figure 1. PAH concentrations in grasses and milk from rural and urban farms. 


\section{Conclusion}

PAH concentrations in grass are only slightly higher in urban versus rural farms, suggesting a rapid dilution of atmospheric PAH point sources. PAH concentrations in urban and rural milk are statistically equal. Further work is under way to pinpoint the origin of milk PAHs using isotope tracers.

\section{Acknowledgements}

We thank the French National Institute of Agronomical Research (INRA) for financial support. We are indebted to the farmers who kindly accepted to collaborate to this investigation. For confidentiality reasons, the locations of the farms are not disclosed

\section{References}

Baek S.O., Field R.A., Goldstone M.E., Kirk P.W., Lester J.N., Perry R. (1991) A review of atmospheric polycyclic aromatic hydrocarbons: sources, fate and behavior. Water Air Soil Pollut 60, 279-300.

Baumard P., Budzinski H., Garrigues P. (1997) Analytical procedure for the analysis of PAHs in biological tissues by gas chromatography coupled to mass spectrometry: application to mussels. Fresenius J Anal Chem 359, 502-509.

Bryselbout C., Henner P., Carsignol J., Lichtfouse E. (2000) Polycyclic aromatic hydrocarbons in highway plants and soils. Evidence for a local distillation effect. Analusis 28, 32-35.

Edwards N.T. (1983) Polycyclic aromatic hydrocarbons (PAH's) in the terrestrial environment. A review. J Environ Qual 12, 427-441.

Eisele G.R. (1985) Naphthalene distribution in tissues of laying pullets, swine, and dairy cattle. Bull Environ Contam Toxicol 34, 549-556.

Freeman D.J., Cattell F.C.R. (1990) Woodburning as a source of atmospheric polycyclic aromatic hydrocarbons. Environ Sci Technol 24, 1581-1585.

Henner P., Schiavon M., Morel J.L., Lichtfouse E. (1997) Polycyclic aromatic hydrocarbon (PAH) occurrence and remediation methods. Analusis 25, M56-M59.

Lichtfouse E., Apitz S., Nanny M. (Eds) (1999) The Biogeochemistry of Polycyclic Aromatic Hydrocarbons. Org Geochem 30, 873-969.

Lichtfouse E., Budzinski H., Garrigues P., Eglinton T. (1997) Ancient polycyclic aromatic hydrocarbons in modern soils: 13C, 14C and biomarker evidence. Org Geochem 26, 353-359.

McLachlan M.S. (1995) Accumulation of PCDD/F in an agricultural food chain. Organohalogen Comp 26, 105-108.

McRae C., Sun C.-G., Snape C., Fallick A.E., Taylor D. (1999) $\delta^{13} C$ values of coal-derived PAHs from different processes and their application to source apportionment. Org Geochem 30, 881-889.

Richnow H.H., Seifert R., Kästner M., Mahro B., Horsfield B., Tiedgen U., Böhm S., Michaelis W. (1995) Rapid screening of PAH-residues in bioremediated soils. Chemosphere 31, 3991-3999.

SAS. (1996). SAS Institute Incorporation. Cary, NC.

Simonich S.L., Hites R.A. (1994) Importance of vegetation in removing polycyclic aromatic hydrocarbons from the atmosphere. Nature 370, 49-51.

Sims R.C, Overcash M.R. (1983) Fate of polynuclear aromatic compounds (PNAs) in soilplant systems. Residue Reviews 88, 1-68.

Tissot B., Califet-Debyser Y., Deroo G., Oudin J.L. (1971) Origin and evolution of hydrocarbons in Early Toarcian shales, Paris Basin, France. Amer Assoc Petrol Geol Bull 55, 2177-2193. 
Travis C.C., Arms A.D. (1988) Bioconcentration of organics in beef, milk, and vegetation. Environ Sci Technol 22, 271-274.

Trendel J.M., Lohmann F., Kintzinger J.P., Albrecht P., Chiaroni A., Riche C., Cesario M., Guilhem J., Pascard C. (1989) Identification of des-A-triterpenoid hydrocarbons occurring in surface sediments. Tetrahedron 45, 4457-4470.

Wild S.R., Jones K.C. (1995) Polynuclear aromatic hydrocarbons in the United Kingdom environment: a preliminary source inventory and budget. Environ Pollut 88,91-108.

Wilcke W. (2000) Polycyclic aromatic hydrocarbons (PAHs) in soil. A review. J Plant Nutr Soil Sci 163, 229-248.

Wilcke W., Amelung W., Martius C., Garcia M.V.B., Zech W. (2000) Biological sources of polycyclic aromatic hydrocarbons (PAHs) in the Amazonian Rain Forest. J Plant Nutr Soil Sci 163, 27-30.

Wilson S.C., Jones K.C. (1993) Bioremediation of soil contaminated with polynuclear aromatic hydrocarbons (PAHs): a review. Environ Pollut 81, 229-249. 